\title{
Difference of seminal plasma and sperm proteins in good and poor freezability boar
} ejaculates

\author{
J. Rungruangsak, J. Suwimonteerabutr, K. Buranaamnuay, S. Asawakarn, \\ N. Chantavisoote, T. Pisitkun, K. Chaweewan and P. Tummaruk ${ }^{*}$
}

\begin{abstract}
The present study was performed to compare the expression of sperm proteins, i.e. triosephosphate isomerase (TPI) and acrosin binding protein (ACRBP) and seminal plasma proteins, i.e. glutathione peroxidase 5 (GPX5) and fibronectin 1 (FN1), in boar semen with good, moderate and poor freezability. The study was conducted by determining the protein contents in 32 sperm samples and 38 seminal plasma samples of semen. The ejaculated semen was divided into two portions: the first portion was centrifuged to separate the pellet of sperm from the seminal plasma and the second portion was cryopreserved. After thawing, the ejaculates were classified into three groups according to their post-thawed sperm motility: good $(60.2 \pm 1.7 \%)$, moderate $(29.3 \pm 2.0 \%)$ and poor $(16.6 \pm 2.2 \%)$ freezabilities. The expressions of GPX5 and FN1 in seminal plasma and
\end{abstract}

TPI and ACRBP in sperm were determined using Western blot analysis. It was found that, for sperm proteins, the level of TPI was negatively correlated with the post-thawed total sperm motility $(\mathrm{r}=-0.38, P=0.029)$. For seminal plasma proteins, the level of FN1 in the seminal plasma was positively correlated with the post-thawed total sperm motility ( $r$ $=0.37, P=0.021)$ and progressive motility $(r=$ $0.39, P=0.016$ ). The expression of GPX5 was not correlated with any of the frozen-thawed sperm qualities $(P>0.05)$. In conclusions, boar semen containing a high level of FN1 in seminal plasma has better freezability. Frozen-thawed sperm motility was positively correlated with the level of FN1 in boar seminal plasma and negatively correlated with TPI in boar spermatozoa.

Key words: boar; cryopreservation; freezability; protein; sperm

Janyaporn RUNGRUANGSAK, Semen Quality Control and Research Section, Bureau of Biotechnology in Livestock Production, Department of Livestock Development, Muang, Pathum Thani, 12000 Thailand; Junpen SUWIMONTEERABUTR, Swine Reproduction Research Unit, Department of Obstetrics, Gynaecology and Reproduction, Faculty of Veterinary Science, Chulalongkorn University, Bangkok 10330, Thailand; Kakanang BURANAAMNUAY, Institute of Molecular Biosciences, Mahidol University 25/25 Phuttamonthon 4 Rd., Salaya, Nakhon Pathom 73170, Thailand; Sariya ASAWAKARN, Biochemistry Unit, Department of Physiology, Faculty of Veterinary Science, Chulalongkorn University, Bangkok, 10330, Thailand; Naphat CHANTAVISOOTE, Trairak PISITKUN, Chulalongkorn University Systems Biology, Faculty of Medicine, Chulalongkorn University, Bangkok, 10330, Thailand; Kamon CHAWEEWAN, Swine Research and Development Centre, Department of Livestock Development, Nakhon Ratchasima, Thailand; Padet TUMMARUK*, DVM, MSc, PhD, Swine Reproduction Research Unit, Department of Obstetrics, Gynaecology and Reproduction, Faculty of Veterinary Science, Chulalongkorn University, Bangkok 10330, Thailand, (Corresponding author, e-mail: Padet.@@chula.ac.th) 


\section{Introduction}

In the current global swine industry, more than $90 \%$ of mating is performed by artificial insemination (AI) and over 99\% of the semen used for AI in practice is extended fresh semen (Yeste, 2015; Knox, 2016; Žura Žaja et al., 2016). Currently, less than $1 \%$ of insemination in pigs is carried out using frozen-thawed semen (Yeste, 2016; Chanapiwat and Kaeoket, 2020). This is because AI, using extended fresh semen, results in a higher conception rate and litter size compared to frozenthawed semen (Chanapiwat et al., 2014). However, the limitation of using of extended fresh semen in the AI industry is that the semen must be stored at 15-20 ${ }^{\circ} \mathrm{C}$ for no longer than 3-7 days. Although many extenders have been developed to increase the lifespan of extended fresh semen, boar semen quality can be maintained for only a short period of time (Waberski et al., 2019; Chanapiwat and Kaeoket, 2021). Thus, superior genetic boars cannot be preserved for a long time by using conventional extended fresh semen. Therefore, cryopreservation of boar semen is the only method to preserve superior genetic boar semen (Jovičić et al., 2020). Moreover, cryopreserved boar semen can be exported across countries for improving swine genetics (Suwimonteerabutr et al., 2021). Another advantage of using frozen-thawed boar semen is the limitation of the risk of disease transmission among herds. Presently, cryopreservation of boar semen has been developed for the swine industry both in pellet form and straws (Eriksson et al., 2002; Buranaamnuay et al., 2009). However, low fertility rate of sows following AI using frozen-thawed boar semen is still commonly observed (Buranaamnuay et al., 2010; Chanapiwat et al., 2014). From the commercial point of view, the main business for boar semen cryopreservation is trading genetics across countries (Waberski et al.,
2019). Moreover, improving the freezing procedure for boar semen may also help to develop preserved sex-sorted semen (Johnson et al., 2005). These data indicate the importance of further development in boar semen freezing technology.

The frozen-thawed boar semen process causes a significant reduction in sperm motility, viability, acrosome integrity, DNA integrity and fertilising ability (Yeste, 2016; Rungruangsak et al., 2021; Suwimonteerabutr et al., 2021). Studies have been conducted to improve the quality of frozen-thawed boar semen including the cryopreservation process, semen extender, thawing media and searching for a freezability marker (Buranaamnuay et al., 2009; Chanapiwat et al., 2010; Yeste, 2015; Jovičić et al., 2020). The main problem with frozen-thawed boar semen quality is cryoinjury (Yeste, 2016; Jovičić et al., 2020). The swine industry continues to request a better sperm protective extender for either fresh or frozen-thawed boar semen (Waberski et al., 2019). Therefore, additional studies on the protein components in either seminal plasma or sperm cells that have protective properties on extended boar semen will eventually helpful to improve the semen cryopreservation technology (Rodriguez-Martinez, 2019). In practice, the boar semen can be classified into two groups according to its ability to withstand cryopreservation procedures, i.e. good and poor freezability ejaculates (Chanapiwat et al., 2010). Previous studies have demonstrated that these individual variations maybe associated with sperm proteins (Vilagran et al., 2013; Vilagran et al., 2015). Therefore, recent cryopreservation advanced research seeks a protein marker to predict ejaculate freezability (Yeste, 2015; Jovičić et al., 2020). So far, a number of proteins marker from both sperm and seminal plasma have been detected to be related 
to ejaculate freezability (RodriguezMartinez, 2019). However, the results from different studies and different population of boars are still controversial (Thurston et al., 2002; Yeste et al., 2013; Llavanera et al., 2019; Valencia et al., 2020; Fraser et al., 2020). The difference in genetics could be responsible for these freezability differences (Thurston et al., 2002). Moreover, Yeste et al. (2013) found that poor freezability ejaculates were less resistant and had a poorer integrity of nucleoprotein structure than good freezability ejaculates. Nevertheless, during the past decade, a number of studies still reported a significant association between various sperm and/ or seminal plasma proteins and the freezability of boar semen (Casas et al., 2010; Vilagran et al., 2013). In practice, the main problem is to classify good and poor ejaculates before starting cryopreservation procedures. Since conventional sperm evaluation cannot predict ejaculate freezability in boars, identifying protein markers is therefore interesting (Yeste, 2016). In previous studies, an addition of $50 \%$ of seminal plasma from good freezability boar to frozen-thawed sperm improved the quality of frozen-thawed sperm of poor freezability boars (Kaeoket et al., 2011; Fernandez-Gago et al., 2013). Vilagran et al. (2015) found that fibronectin 1 (FN1) was a positive freezability marker of boar semen. Additionally, GPX5 has also been found to be related to protection of the sperm and plasma membrane against peroxides (Noblanc et al., 2011; Vilagran et al., 2015) and was positively correlated with farrowing rates (Novak et al., 2010). Wysocki et al. (2015) found that N-acetylB-hexosaminidase protein in boar seminal plasma was negatively correlated with sperm viability, motility and lipid peroxidation. Furthermore, Vilagran et al. (2013) found a positive relationship between the amount of acrosin binding protein (ACRBP) and post-thawed motility in boar sperm. On the other hand, Triosephosphateisomerase (TPI) has been described as a negative freezability marker (Vilagran et al., 2013). Nevertheless, none of these protein markers has been used in the swine industry. Moreover, additional information needs to be obtained from different population of boars and different environment before the global implementation can be done.

In the previous study, both GPX5 and TPI are markers of boar semen quality (Vilagran et al., 2016). Novak et al. (2010) found a positive correlation between GPX5 and litter size in pigs. Some sperm proteins, e.g. TPI, involved in zona pellucida binding (Petit et al., 2013), are associated with litter size in pigs (Kwon et al., 2015). In fresh semen, Vilagran et al. (2016) demonstrated that TPI levels in poor sperm quality boars were higher than in good sperm quality boars. However, a clinical study conducted under field conditions has not been done. To confirm these findings, investigation of these protein markers in different populations of boars needs to be done before clinical implementation. Moreover, investigation of these protein markers and freezability of boar semen raised under tropical climate conditions has never been done. Therefore, the aim of the present study was to investigate the difference in seminal plasma and sperm proteins in good and poor freezability boar ejaculates. The number of selected proteins in seminal plasma (i.e. FN1, GPX5) and sperm proteins (i.e. ACRBP, TPI) in relation to sperm motility patterns were also determined.

\section{Materials and Methods}

\section{Animals}

This experiment followed the guidelines of the ethical principles and guidelines for the use of animals for scientific purposes by the National Research Council of Thailand and was 
approved by the Institutional Animal Care and Use Committee in accordance with the university regulations and policies governing the care and use of experimental animals (animal use protocol no. 1631032). The experiment was conducted at the Swine Research and Development Centre, Department of Livestock Development, Nakhon Ratchasima, Thailand. Semen samples were collected from 27 boars (i.e., 13 Duroc, 8 Landrace and 6 Yorkshire). A total of 38 ejaculates were used for seminal plasma protein studies and 32 ejaculates were used in spermatozoa protein studies. All boars were proven sires routinely used for semen collection and were selected based on their good semen quality. To be included in the experiment, the boar ejaculates had to have $\geq 70 \%$ subjective motility and $\geq 75 \%$ normal morphology. The boars were housed in a conventional open-housing system and were allocated to individual pens. The semen was collected using a gloved-hand technique. The interval between each semen collection was 5-7 days.

\section{Preparation of seminal plasma and sperm samples}

The semen was filtered through a semen filter bag and divided equally into two portions. The first portion was prepared for determination of seminal plasma and sperm protein expression. The second portion was used for semen cryopreservation (see below). The first portion of semen was centrifuged at 800 $\times \mathrm{g}$ at $15{ }^{\circ} \mathrm{C}$ for $10 \mathrm{~min}$ to separate the pellet of sperm from the seminal plasma. Following this step, the supernatant was centrifuged at $10,000 \times \mathrm{g}$ at $4{ }^{\circ} \mathrm{C}$ for $15 \mathrm{~min}$ and the supernatant was investigated under a phase contrast microscope (Olympus, Hamburg, Germany) at $\times 200$ magnifications to verify that they did not contain sperm. Then, the seminal plasma sample was collected in a cryotube and kept in liquid nitrogen $\left(-196{ }^{\circ} \mathrm{C}\right)$. Next, both sperm and seminal plasma samples were stored at $-80{ }^{\circ} \mathrm{C}$ before protein extraction and analysis.

\section{Semen cryopreservation}

The second portion of the semen was cryopreserved according to our previous protocol (Buranaamnuay et al., 2009) with some modifications. Briefly, the semen was diluted $(1: 1, \mathrm{v} / \mathrm{v})$ in extender I (Duragen ${ }^{\circledR}$, Magapor, Zaragoza, Spain). The diluted semen was stored at $15{ }^{\circ} \mathrm{C}$ for $2 \mathrm{~h}$. Next, the semen was centrifuged at $800 \times \mathrm{g}$ at $15{ }^{\circ} \mathrm{C}$ for $10 \mathrm{~min}$. The sperm pellet was resuspended in extender II (lactose-egg yolk (LEY) extender: $80 \mathrm{~mL}$ of $11 \%$ lactose solution and $20 \mathrm{~mL}$ egg yolk) to achieve a $1.5 \times 10^{9}$ sperm per mL concentration. The extended semen was cooled to $4{ }^{\circ} \mathrm{C}$ for $2 \mathrm{~h}$. Thereafter, the semen was resuspended and combined with extender III (LEY extender plus 10\% glycerol and 1.5\% Equex STM Paste; Nova Chemical Sales Inc., MA, USA) to a final sperm concentration of $1.0 \times 10^{9}$ sperm per $\mathrm{mL}$ and loaded into 0.5 PVCFrench straws (IMV, IMV Technologies, France). For the freezing process, the straws were placed at approximately 4 $\mathrm{cm}$ over the liquid nitrogen level for 15 $\min \left(-120{ }^{\circ} \mathrm{C}\right)$ and plunged into liquid $\mathrm{N}_{2}$ $\left(-196^{\circ} \mathrm{C}\right)$ for storage.

\section{Thawing procedure and semen evaluation}

For the thawing procedure, the straws were plunged into $50^{\circ} \mathrm{C}$ water for $12 \mathrm{sec}$. Next, the thawed semen was diluted in Duragen ${ }^{\circledR}$ extender (Magapor, Zalagoza, Spain) 1:10 (v:v) and post-thawed sperm qualities (see below) evaluated. The postthawed semen was classified into three groups according to the post-thawed total sperm motility, i.e. poor $(\leq 20 \%)$, moderate $(21-40 \%)$ and good $(>40 \%)$. The sperm concentration of the frozen semen was evaluated using a Bürker haemacytometre (Boeco, Hamburg, 
Germany). The total motility and sperm kinematic parameters were evaluated at $37{ }^{\circ} \mathrm{C}$ using a computer assisted sperm analysis system (IVOSII, HamiltonThorne $^{\circledR}$, Beverly, MA, USA). The semen parameters evaluated included total sperm motility, progressive motility and kinematic characteristic parameters. The sperm kinematic characteristics included straight-line velocity (VSL, $\mu \mathrm{m} / \mathrm{sec}$ ), curvilinear velocity (VCL, $\mu \mathrm{m} /$ $\mathrm{sec}$ ), average path velocity (VAP, $\mu \mathrm{m} /$ sec), linearity (LIN, \%), straightness (STR, \%), wobble coefficient (WOB, \%), mean lateral head displacement $(\mathrm{ALH}$, $\mu \mathrm{m})$ and beat cross frequency (BCF, $\mathrm{Hz}$ ) (Pearodwong et al., 2019).

\section{Sperm viability}

The viability of the boar spermatozoa was determined using SYBR-14/ Ethidiumhomodimer-1 (EthD-1) (Fertilight $^{\circledR}$, Sperm Viability Kit, Molecular Probes Europe, Leiden, The Netherlands) (Pearodwong et al., 2019). Briefly, $10 \mu \mathrm{L}$ of the semen sample was diluted using $140 \mu \mathrm{L}$ of thawing medium. Thereafter, $50 \mu \mathrm{L}$ of diluted semen was mixed with $2.7 \mu \mathrm{L}$ of SYBR-14 and $10 \mu \mathrm{L}$ of EthD-1. After incubation at $37^{\circ} \mathrm{C}$ for $20 \mathrm{~min}, 200$ sperm were assessed $(\times 1000)$ under a fluorescent microscope. The nuclei of sperm with an intact plasma membrane were stained green with SYBR-14, while those with damaged membranes were stained red with EthD-1. Sperm were classified into two types; live sperm, stained green and dead sperm, stained red.

\section{Acrosome integrity}

An aliquot $(10 \mu \mathrm{L})$ of diluted semen was mixed with an equal volume of EthD-1 and incubated at $37^{\circ} \mathrm{C}$ for $15 \mathrm{~min}$. Thereafter, $5 \mu \mathrm{L}$ of mixture was spread on a slide and fixed with 95\% ethyl alcohol for 30 seconds. Next, the samples were smeared with $15 \mu \mathrm{L}$ of FITC-PNA solution (FITC-PNA in phosphate buffer saline (PBS) 1:10, v/v). The slide was placed in a moist chamber at $4{ }^{\circ} \mathrm{C}$ for 30 min. The sample was rinsed gently with PBS and dried. A total of 200 sperm cells were determined under a fluorescent microscope using $\times 1000$ magnification . The acrosome of the sperm was categorised as an intact acrosome, reacted acrosome or loose acrosome (Chanapiwat et al., 2009).

\section{Plasma membrane integrity}

The integrity of the plasma membrane was assessed using a short hypo-osmotic swelling test (sHOST). Briefly, a $100 \mu \mathrm{L}$ semen sample was incubated with 1,000 $\mu \mathrm{L}$ of hypo-osmotic solution at $38{ }^{\circ} \mathrm{C}$ for $30 \mathrm{~min}$. After incubation, $200 \mu \mathrm{L}$ of semen and hypo-osmotic solution was loaded on $1,000 \mu \mathrm{L}$ of hypo-osmotic solution plus 5\% formaldehyde (Merck, Darmstadt, Germany). A $10 \mu \mathrm{L}$ sample was placed on a warm slide with a cover slip. In total, 200 sperm were evaluated using bright-field microscopy at x 400 magnification. The positive result (coiled tail) was defined as sperm having active plasma membrane function (Samardžija et al., 2008; Buranaamnuay et al., 2009).

\section{Mitochondrial activity}

The mitochondrial activity was assessed by JC-1 (Molecular Probes, Molecular Probes Inc., Eugene, OR, USA). The stock solutions consisted of $0.153 \mathrm{mM}$ JC-1 in DMSO, 0.02mM SYBR14 and $2.4 \mathrm{mM}$ PI. The staining solution contained $1.6 \mu \mathrm{l}$ of $0.153 \mathrm{mM}$ JC-1, $1.0 \mu \mathrm{L}$ of $0.02 \mathrm{mM}$ SYBR-14, $1.6 \mu \mathrm{L}$ of $2.4 \mathrm{mM}$ PI in $100 \mu \mathrm{L}$ Hepes-buffered medium. A total of $12.5 \mu \mathrm{L}$ of frozen-thawed boar semen was incubated with the staining solution $(25 \mu \mathrm{L})$ at $37{ }^{\circ} \mathrm{C}$ for $30 \mathrm{~min}$. Next, the stained sperm were examined under a fluorescent microscope at x 1,000 magnification. The sperm stained with JC-1, displaying green fluorescence, were defined as mitochondria with low to moderate membrane potential, while the sperm stained with JC-1, displaying 
red-orange fluorescence, were defined as mitochondria with high membrane potential (Garner et al., 1997).

\section{Quantification of total protein}

The seminal plasma was separated from sperm by centrifugation at $800 \times$ $\mathrm{g}$ at $15{ }^{\circ} \mathrm{C}$ for $10 \mathrm{~min}$. The supernatant was centrifuged at $10,000 \times \mathrm{g}$ at $4{ }^{\circ} \mathrm{C}$ for $15 \mathrm{~min}$ and stored at $-80{ }^{\circ} \mathrm{C}$. The sperm pellet was washed with PBS to eliminate the remaining traces of seminal plasma and centrifuged at 800 $\times \mathrm{g}$ at $15^{\circ} \mathrm{C}$ for $10 \mathrm{~min}$. Thereafter, the sperm pellet was resuspended with PBS with protease inhibitor (Gibco BRL, Life Technologies Ltd., Paisley, UK). Protein was extracted according to the protocol described by Vilagran et al. (2013) with some modifications. Briefly, after washing three times with PBS at $400 \times$ $\mathrm{g}$, the sperm pellets were resuspended in PBS at a concentration of $50 \times 10^{6}$ sperm per sample. The pellet of sperm was added to $400 \mu \mathrm{L}$ of lysis buffer $(2 \%$ sodium dodecyl sulphate, affymetrix/ USB, ThermoFisher Scientific, Waltham, MA, USA), $1.0 \mathrm{M}$ Triethylammonium bicarbonate buffer (Sigma-Aldrich, USA) and protease inhibitor. The samples were lysed by homogenisers (VCX750, VibraCell ${ }^{\mathrm{TM}}, \mathrm{USA}$ ) in ice conditions on $10 \mathrm{~s}$ off $5 \mathrm{~s} \mathrm{amp} \mathrm{30 \%} \mathrm{for} 5 \mathrm{~min}$ and subsequently centrifuged for $10 \mathrm{~min}$ at $10,000 \times \mathrm{g}$ at 4 ${ }^{\circ} \mathrm{C}$. The supernatants were stored at -80 ${ }^{\circ} \mathrm{C}$. The total proteins were quantified using the Pierce ${ }^{\mathrm{TM}}$ BCA Protein Assay Kit (ThermoFisher Scientific, Waltham, MA, USA).

\section{Western blot analysis and quantification of protein density}

Seminal plasma and spermatozoa protein $(20 \mu \mathrm{g})$ were subjected to sodium dodecyl sulphate polyacrylamide gel electrophoresis (SDS-PAGE). Equal amounts of total protein were denatured in an electrophoresis sample buffer (0.5 M Tris-Hcl pH 6.8, glycerol, SDS,
Bromophenol blue, B-mercaptoethanol). After boiling at $95{ }^{\circ} \mathrm{C}$ for $5 \mathrm{~min}$, proteins from each sample were measured in $12.5 \%$ polyacrylamide gel. Thereafter, the proteins were transferred into nitrocellulose membranes (NC) at a constant 25 volts for $30 \mathrm{~min}$. The NC membrane was incubated with Odyssey blocking buffer (1×TBS) solutions $\left(\mathrm{Odyssey}^{\circledR}\right.$, Li-Cor, Lincoln, NE, USA) at room temperature for $1 \mathrm{~h}$. The membranes were washed using $1 \times$ Towbin's buffer with $0.01 \%$ Tween-20 (Omnia, Huntington Beach, CA, USA) and incubated with anti-FN1 rabbit (Fab2413, Abcam, Cambridge, MA, USA) at a dilution of 1:1,000 or anti-GPX5 rabbit (SC50498, Santacruz Biotechnology, Chicago, IL, USA) at a dilution of 1:200 for seminal plasma protein. For sperm protein, the samples were incubated with anti-ACRBP rabbit (ab64809, Abcam, Cambridge, MA, USA), anti-TPI rabbit (ab96696, Abcam, Cambridge, MA, USA) or anti $\alpha$-tubulin antibody $11 \mathrm{H} 10$ (Cell Signalling Technology, Danvers, MA, USA) at a dilution of $1: 1,000$ at $4{ }^{\circ} \mathrm{C}$ for 24 h. After washing with $1 \times$ Towbin buffer many times, the NC membranes were incubated with donkey anti-Rabbit IgG antibody (IRDye ${ }^{\circledR}$ 680RD, Fremont, CA, USA) at a dilution of $1: 10,000$ in a dark room for $60 \mathrm{~min}$. After washing with $1 \times$ Towbin buffer, the NC membranes were evaluated. For protein quantification, the reactive protein band was developed by fluorescent assay. Briefly, the reactive protein band was visualised by Odyssey ${ }^{\circledR}$ (Odyssey $^{\circledR}$ Fc infrared imaging system, LI-COR Biosciences, Lincoln, NE, USA). Then, the membrane was scanned by Odyssey $^{\circledR}$. Next, the band density was normalised by Coomassie staining. Briefly, the membranes were stained for 1 min at room temperature with Coomassie brilliant blue R-250 (Imperial protein stain, ThermoFisher Scientific, Waltham, MA, USA) and then the membranes were cleaned with methanol-water (1:1 v:v). 
After cleaning for 20 min with a 1:5:4 (v:v:v) acetic acid-ethanol-water solution, the membranes were washed twice with distilled water. The membranes were air dried and photographs were taken by using the ChemiDoc Imaging System (BioRad, CA, USA) and were analysed using Image J Software (version 1.6, National Institutes of Health, USA). The density of each band was calculated according to Vilagran et al. (2015). For sperm proteins, the band densities of interesting proteins (ACRBP and TPI) were normalised by using $\alpha$-tubulin as an internal standard. Sperm protein content $=$ band of interest (intensity) - tubulin (intensity). Each sample was normalised by dividing the density of the band corresponding to $\alpha$-tubulin using Image J Software.

\section{Statistical analyses}

The statistical analyses were carried out using SAS version 9.4 (SAS Inst. Inc., Cary, NC, USA). Descriptive statistics on boar semen qualities and the number of proteins were calculated. Continuous data were presented as least square means \pm SEM. Discrete data were presented as percentages. Continuous data included total sperm motility, progressive motility, subjective motility, sperm kinematic characteristic parameters (i.e. VCL, VSL, VAP, LIN, STR, WOB, ALH and BCF), sperm viability, acrosome integrity and functional integrity of the sperm plasma membrane. Pearson's correlation was conducted to determine the association between sperm quality parameters and the levels of protein contents of the boar sperm (ACRBP and TPI) and seminal plasma (FN1 and GPX5). Additionally, post-thawed boar semen was classified into three classes according to the postthawed total sperm motility, i.e. poor $(\leq$ $20 \%)$, moderate $(21-40 \%)$ and good (> $40 \%)$. The protein content in the seminal plasma (i.e. FN1 and GPX5) and sperm (i.e. ACRBP and TPI) was compared between groups using ANOVA. Least square means were obtained from the statistical models and compared among groups using the Tukey-Kramer adjustment for multiple comparisons. For all analyses, differences of $P<0.05$ were regarded as statistically significant.

\section{Results}

Across group, the average semen volume, sperm concentration and total sperm per ejaculates were $247 \pm 74.6 \mathrm{~mL}$, $283 \pm 127 \times 10^{6} \mathrm{sperm} / \mathrm{mL}$ and $66.5 \pm$ $31.2 \times 10^{9}$ sperm, respectively. For fresh semen, the percentage of sperm having bent tail, coil tail, distal cytoplasmic droplet and proximal cytoplasmic droplet were $13.0 \%, 1.3 \%, 5.4 \%$ and $6.5 \%$, respectively. For frozen-thawed semen, the percentage of sperm having bent tail, coil tail, distal cytoplasmic droplet and proximal cytoplasmic droplet were $22.4 \%, 2.2 \%, 11.3 \%$ and $13.8 \%$, respectively. The percentage of sperm with morphologically normal was $82.1 \%$ and $74.6 \%$ for fresh and frozen-thawed semen, respectively. The average frozen-thawed sperm viability, acrosome integrity, plasma membrane integrity, mitochondrial activity, total motility, progressive motility and sperm kinematic characteristics as determined by CASA are presented in Table 1.

The expression of sperm proteins including TPI and ACRBP in good, moderate and poor freezability sperm are demonstrated in Figure 1. The expression of seminal plasma protein patterns including GPX5 and FN1 in good, moderate and poor freezability sperm are demonstrated in Figure 2.

The correlation analyses among sperm quality parameters and amount of sperm and seminal plasma proteins of the frozen-thawed boar sperm are presented in Table 1. Interestingly, the level of FN1 in the seminal plasma was positively correlated with the postthawed total sperm motility $(\mathrm{r}=0.37, P=$ 
$0.021)$ and progressive motility $(r=0.39$, $P=0.016$ ). The level of TPI in the sperm was negatively correlated with the postthawed total sperm motility $(\mathrm{r}=-0.38, P$ $=0.029$ ). Neither GPX5 nor ACRBP were correlated with any of the frozen-thawed sperm qualities $(P>0.05)$.

Of all the semen samples, $31.6 \%$, $44.7 \%$ and $23.7 \%$ had good, moderate and poor freezability, respectively. Fresh and frozen-thawed boar semen characteristics in good, moderate and poor sperm freezability groups are presented in Table 2. On average, the total motility of the frozen-thawed sperm having good, moderate and poor freezabilities was $54.1 \pm 1.3 \%, 32.1$ $\pm 1.3 \%$ and $14.7 \pm 1.3 \%$, respectively $(P$ $<0.001)$. Similarly, the sperm viability of the frozen-thawed sperm having good, moderate and poor freezabilities was $60.1 \pm 1.3 \%, 59.5 \pm 1.3 \%$ and 44.7 $\pm 1.3 \%$, respectively $(P<0.001)$. On average, the levels of the selected sperm proteins including TPI and ACRBP were $3.79 \pm 1.40$ and $1.87 \pm 1.01$ density/ $\mathrm{mm}^{2}$, respectively. The levels of sperm proteins in good, moderate and poor sperm freezability groups are presented in Table 1. Both TPI and ACRBP in moderate freezability ejaculates was higher $(P<0.05)$ than good freezability ejaculates (Table 2). On average, the levels of the selected seminal plasma proteins including FN1 and GPX5 were $7.08 \pm 2.88$ and $14.04 \pm 10.94$ density/ $\mathrm{mm}^{2}$, respectively. The levels of seminal plasma proteins in good, moderate

Table 1. Pearson's correlation among sperm quality parameters and amount of sperm ( $n=32$ ) and seminal plasma proteins ( $n=38$ ) of frozen-thawed boar sperm.

\begin{tabular}{|c|c|c|c|c|c|}
\hline \multirow{2}{*}{ Sperm quality parameters } & \multirow{2}{*}{ Mean \pm SD } & \multicolumn{2}{|c|}{ Sperm } & \multicolumn{2}{|c|}{ Seminal plasma } \\
\hline & & ACRBP & TPI & FN1 & GPX5 \\
\hline Sperm viability (\%) & $58.9 \pm 8.8$ & NS & NS & NS & NS \\
\hline Acrosome integrity (\%) & $60.7 \pm 12.6$ & NS & NS & NS & NS \\
\hline Plasma membrane integrity (\%) & $53.8 \pm 10.9$ & NS & NS & NS & NS \\
\hline Mitochondrial activity (\%) & $63.5 \pm 10.4$ & NS & NS & NS & NS \\
\hline Total motility (\%) & $40.6 \pm 15.8$ & NS & $-0.38^{*}$ & $0.43^{*}$ & NS \\
\hline Progressive motility (\%) & $19.2 \pm 10.3$ & NS & NS & $0.39 *$ & NS \\
\hline \multicolumn{6}{|l|}{ Sperm kinematic characteristics } \\
\hline VSL $(\mu \mathrm{m} / \mathrm{s})$ & $56.0 \pm 8.4$ & NS & NS & NS & NS \\
\hline $\operatorname{VCL}(\mu \mathrm{m} / \mathrm{s})$ & $117.9 \pm 27.5$ & NS & NS & NS & NS \\
\hline $\operatorname{VAP}(\mu \mathrm{m} / \mathrm{s})$ & $69.7 \pm 11.6$ & NS & NS & NS & NS \\
\hline $\operatorname{LIN}(\%)$ & $51.6 \pm 9.4$ & NS & NS & NS & NS \\
\hline STR (\%) & $80.6 \pm 7.0$ & NS & NS & NS & NS \\
\hline WOB $(\%)$ & $61.9 \pm 7.2$ & NS & NS & NS & NS \\
\hline $\mathrm{ALH}(\mu \mathrm{m})$ & $4.8 \pm 1.1$ & NS & NS & NS & NS \\
\hline $\mathrm{BCF}(\mathrm{Hz})$ & $34.5 \pm 3.1$ & NS & NS & NS & NS \\
\hline
\end{tabular}

Significance levels indicated as ${ }^{*} P<0.05,{ }^{* *} 0.05<P<0.01,{ }^{* * *} P<0.001$ and NS $=P>0.05$; VSL ( $\mu \mathrm{m} / \mathrm{s}$ ): straight-line velocity, VCL $(\mu \mathrm{m} / \mathrm{s})$ : velocity curved line, $\operatorname{VAP}(\mu \mathrm{m} / \mathrm{s})$ : velocity average path, LIN (\%): linearity (VSL divided by VCL), STR (\%): straightness, WOB (\%): wobble coefficient, ALH $(\mu \mathrm{m})$ : mean lateral head displacement, BCF $(\mathrm{Hz})$ : beat cross frequency 


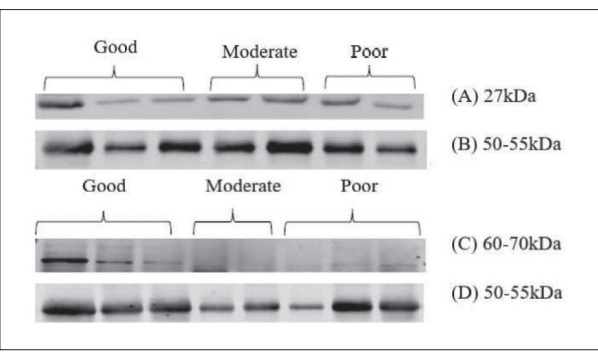

Figure 1. Sperm proteins, i.e. TPI (A), ACRBP (B) in good, moderate and poor freezability sperm. $\alpha$-tubulin (C) and (D) were used as an internal standard in order to normalise the intensity of sperm protein bands

and poor sperm freezability groups are presented in Table 2. The levels of both FN1 and GPX5 in the seminal plasma were not different $(P>0.05)$ among groups (Table 2).

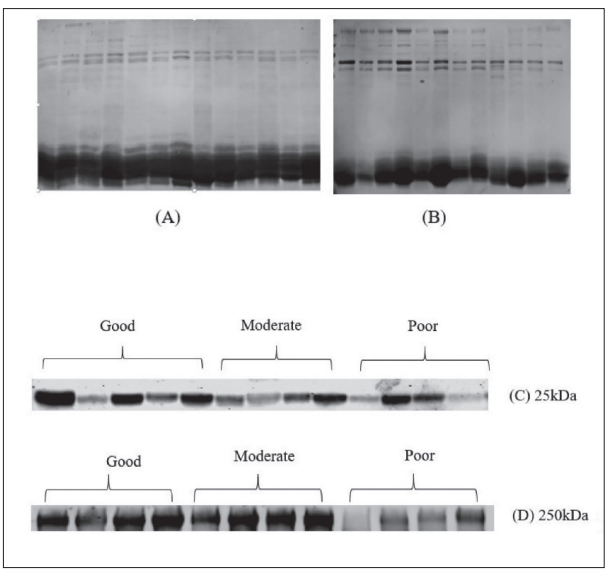

Figure 2. Seminal plasma protein patterns, i.e. GPX5 (C) and FN1 (D) in good, moderate and poor freezability sperm. Coomassie brilliant blue stained membranes were used to normalise the band intensity of seminal plasma proteins (A) and $(B)$

Table 2. Fresh and frozen semen characteristics and amount of sperm and seminal plasma proteins in good, moderate and poor sperm freezability groups (least square means \pm SEM).

\begin{tabular}{|l|c|c|c|}
\hline Variables & \multicolumn{3}{|c|}{ Sperm freezability } \\
\hline Fresh semen & Good & Moderate & Poor \\
\hline Semen volume $(\mathrm{mL})$ & & & \\
\hline Sperm concentration $\left(\times 10^{6} \mathrm{sperm} / \mathrm{mL}\right)$ & $328.3 \pm 24.6$ & $310.9 \pm 25.5$ & $275.0 \pm 53.8$ \\
\hline Total motility (\%) & $83.9 \pm 1.1^{\mathrm{a}}$ & $79.2 \pm 1.1^{\mathrm{b}}$ & $79.2 \pm 2.3^{\mathrm{ab}}$ \\
\hline Progressive motility (\%) & $39.8 \pm 2.0$ & $35.7 \pm 2.1$ & $29.7 \pm 4.4$ \\
\hline Frozen-thawed semen & & & \\
\hline Sperm viability (\%) & $60.1 \pm 1.3^{\mathrm{a}}$ & $59.5 \pm 1.3^{\mathrm{a}}$ & $44.7 \pm 3.6^{\mathrm{b}}$ \\
\hline Total motility (\%) & $54.1 \pm 1.3^{\mathrm{a}}$ & $32.1 \pm 1.2^{\mathrm{b}}$ & $14.7 \pm 2.6^{\mathrm{c}}$ \\
\hline Progressive motility (\%) & $26.9 \pm 1.0^{\mathrm{a}}$ & $14.2 \pm 1.1^{\mathrm{b}}$ & $5.7 \pm 2.2^{\mathrm{c}}$ \\
\hline Sperm protein & & & \\
\hline Number of samples & 12 & 10 & 10 \\
\hline TPI & $3.17 \pm 0.39^{\mathrm{a}}$ & $4.35 \pm 0.43^{\mathrm{b}}$ & $3.97 \pm 0.42^{\mathrm{ab}}$ \\
\hline ACRBP & $1.19 \pm 0.21^{\mathrm{a}}$ & $1.97 \pm 0.23^{\mathrm{b}}$ & $1.35 \pm 0.23^{\mathrm{ab}}$ \\
\hline Seminal plasma protein & & & \\
\hline Number of samples & 13 & 16 & 9 \\
\hline GPX5 & $14.68 \pm 3.10$ & $14.39 \pm 2.80$ & $12.50 \pm 3.74$ \\
\hline FN1 & $8.00 \pm 0.80$ & $6.57 \pm 0.72$ & $6.64 \pm 0.96$ \\
\hline
\end{tabular}

a,b,c different superscripts within rows differ significantly $(P<0.05)$ 


\section{Discussion}

Of all the cryopreserved semen samples, $31.6 \%, 44.7 \%$ and $23.7 \%$ had good, moderate and poor freezability, respectively. The present study demonstrated differences in some seminal plasma (GPX5, FN1) and sperm protein (TPI, ACRBP) contents in good, moderate and poor freezability ejaculates classified according to frozen-thawed boar sperm total motility. In boar seminal plasma, the FN1 content was associated with sperm quality parameters, while GPX5 was not correlated with any of the sperm quality parameters. Fibronectin 1 is a high-molecular-weight $(\sim 250$ $\mathrm{kD})$ glycoprotein in blood plasma, the extracellular matrix, basal lamina and on the cell surface. In humans, FN is associated with sperm maturation, sperm capacitation and fertilisation (Miranda and Tezon, 1992). Fibronectin can stimulate sperm capacitation in the oviduct through the cyclic adenosine monophosphate and protein kinase pathway (Martinez-Leon et al., 2015). In boar, FN1 is one of the most abundant proteins in seminal plasma (Druart et al., 2013). Gonzalez-Cadavid et al. (2014) found that FN1 was negatively correlated with the proportion of tail abnormalities in boar sperm. In the present study, FN1 is a potential freezability marker for boar semen cryopreservation. This finding is in agreement with a previous study (Vilagran et al., 2015). However, the mechanism underlining the effect of FN1 on the freezability of boar semen remains unknown. The functions of the boar seminal plasma proteins include the physiological modulations of sperm function during transport in the female reproductive tract, inhibiting and stabilising activity against enzyme systems and sperm chromatin, immunosuppressive and immunomodulation properties, defence mechanisms of spermatozoa and enzymes in sperm metabolism (Strzezek, 2002). Therefore, the effect of FN1 on the freezability of boar sperm may be associated with the stabilising activity and defence mechanisms of spermatozoa.

In the present study, GPX5 was not associated with the boar sperm freezability. Moreover, the level of GPX5 was not correlated with any of the frozenthawed sperm qualities. Nevertheless, the level of GPX5 was positively correlated with FN1. The present result is in accordance with Vilagran et al. (2015) who found that the GPX5 content was no different between good and poor freezability groups. On the other hand, Barranco et al. (2016) found that the GPX5 concentration was positively associated with total sperm motility, farrowing rate and litter size. Likewise, Vilagran et al. (2016) found a negative correlation between GPX5 and boar semen qualities. However, differences in GPX5 concentration were also found among ejaculate portions, with the first $10 \mathrm{~mL}$ of the sperm rich fraction having a lower GPX5 concentration than the remainder (Barranco et al., 2016). These findings indicated that GPX5 is associated with some semen quality parameters and can be used as a fertility marker of the boars, but it is not associated with the boar sperm freezability.

In the present study, TPI was negatively correlated with boar sperm freezability. Triosephosphate isomerase is a glycolytic enzyme that catalyses the interconversion of dihydroxyacetone phosphate and D-glyceraldehyde 3 phosphate. It is an essential enzyme for sperm capacitation and the acrosome reaction. In previous studies, the inhibition of this enzyme using ornidazole in rat spermatozoa blocked the capacitation process (Bone et al., 2001). Our results agree with Kwon et al. (2015), who revealed that the TPI level was higher in low quality sperm samples. In addition, Vilagran et al. (2013) found that 
the TPI level in poor freezability semen was higher than in good freezability boar semen. Chen et al. (2014) demonstrated that an alteration of proteins, including TPI, occurred after the cryopreservation process. Vilagran et al. (2016) found that this defect was caused by handling after ejaculation, i.e. dilution techniques and cooling process. It could be explained that, due to the lower membrane integrity, a high level of TPI in the sperm head is related to poor sperm freezability. In our study, lower plasma membrane integrity after cryopreservation was found in poor freezability ejaculates compared to moderate and good freezability ejaculates.

Acrosin binding protein plays an important role in the maturation of acrosin (Tardif et al., 2010) and can regulate sperm capacitation and fertilisation (Arcelay et al., 2008). Expression of ACRBP occurs when sperm are capacitating and the levels of the protein in capacitated sperm and frozenthawed sperm groups are similar. In the present study, the level of ACRBP was not different among freezability groups. Nonetheless, ACRBP was positively correlated with the percentage of total sperm motility after thawing. Vilagran et al. (2013) found that ACRBP may be involved in acrosin pathway maturation, where good freezability sperm had a high ability of acrosin maturation.

In conclusion, boar sperm proteins (i.e. TPI) and seminal plasma proteins (i.e. FN1) were significantly associated with boar sperm freezability. Boar ejaculates with a high level of FN1 had a higher freezability than those with a low level of FN1. This finding increases the possibility of improving boar sperm cryopreservation technology. Future work is required to investigate the mechanism behind the effect of these markers as well as the clinical application of these markers in boar semen cryopreservation.

\section{Acknowledgement}

Financial support for this study was provided by the $90^{\text {th }}$ Anniversary of Chulalongkorn University Fund (Grant number GCUGR1125604078M). Chulalongkorn University supported the One Health Research Cluster. P. Tummaruk was awarded the Thailand Science Research and Innovation (TSRI) Senior Researcher Scholar (RTA6280013). J. Rungruangsak is a grantee of the Research and Researcher for Industry RRI Master of Science Degree Programme, TSRI (MSD59I0067). The authors are grateful to the embryo transfer technology and germplasm research centre and their staff for help with boar semen processing. All boar semen samples were provided by the Swine Research and Development Centre, Department of Livestock Development, Nakhon Ratchasima, Thailand.

\section{References}

1. ARCELAY, E., A. M. SALICIONI, E. WERTHEIMER and P. E. VISCONTI (2008): Identification of proteins undergoing tyrosine phosphorylation during mouse sperm capacitation. Int. J. Dev. Biol. 52, 463-472.

2. BARRANCO, I., A. TVARIJONAVICIUTE, C. PEREZ-PATINO, A. VICENTE-CARRILLO, I. PARRILLA, J. J. CERON, E. A. MARTINEZ, H. RODRIGUEZ-MARTINEZ and J. ROCA (2016): Glutathione peroxidase 5 is expressed by the entire pig male genital tract and once in the seminal plasma contributes to sperm survival and in vivo fertility. PLoS One 11, e0162958.

3. BONE, W., A. R. JONES, C. MORIN, E. NIESCHLAG and T.G.COOPER (2001): Susceptibility of glycolytic enzyme activity and motility of spermatozoa from rat, mouse, and human to inhibition by proven and putative chlorinated antifertility compounds in vitro. J. Androl. 22, 464-470.

4. BURANAAMNUAY, K., P. TUMMARUK and M. TECHAKUMPHU (2010): Intra-uterine insemination with low numbers of frozen-thawed boar spermatozoa in spontaneous and induced ovulating sows under field conditions. Livest. Sci. 131, 115-118.

5. BURANAAMNUAY, K., P. TUMMARUK, J. SINGLOR, H. RODRIGUEZ-MARTINEZ and M. TECHAKUMPHU (2009): Effects of straw volume and Equex-STM on boar sperm quality after cryopreservation. Reprod. Dom. Anim. 44, 69-73.

6. CASAS, I., S. SANCHO, J. BALLESTER, M. BRIZ, E. PINART, E. BUSSALLEU, M. YESTE, A. FABREGA, J.E. RODRIGUEZ-GIL and S. BONET (2010): The HSP90AA1 sperm content and the prediction of the boar ejaculate freezability. Theriogenology 74 , 940-950.

7. CHANAPIWAT, P., K. KAEOKET and P. TUMMARUK (2009): Effects of DHA-enriched hen egg yolk and L-cysteine supplementation on quality of cryopreserved boar semen. Asian J. Androl. 11, 600-608. 
8. CHANAPIWAT, P., K. KAEOKET and P. TUMMARUK (2010): The sperm DNA damage after cryopreservation of boar semen in relation to post-thawed semen qualities, antioxidant supplementation and boar effect. Thai J. Vet. Med. 40, 187-193.

9. CHANAPIWAT, P. and K. KAEOKET (2020): Cryopreservation of boar semen: where we are. Thai J. Vet. Med. 50, 283-295.

10. CHANAPIWAT, P. and K. KAEOKET (2021): L-cysteine prolonged fresh boar semen qualities, but not for docosahexaenoic acid. Czech J. Anim. Sci. 66, 21-28.

11. CHANAPIWAT, P., E. O. OLANRATMANEE, K. KAEOKET and P. TUMMARUK (2014): Conception rate and litter size in multiparous sows after intrauterine insemination using frozenthawed boar semen in a commercial swine herd in Thailand. J. Vet. Med. Sci. 76, 1347-1351.

12. CHEN, X., H. ZHU, C. HU, H. HAO, J. ZHANG, K. LI, X. ZHAO, T. QIN, K. ZHAO, H. ZHU and D. WANG (2014): Identification of differentially expressed proteins in fresh and frozen-thawed boar spermatozoa by iTRAQ-coupled 2D LC-MS/MS. Reproduction 147, 321-330.

13. DRUART, X., J. P. RICKARD, S. MACTIER, P. L. KOHNKE, C. M. KERSHAW-YOUNG, R. BATHGATE, Z. GIBB, B. CROSSETT, G. TSIKIS, V. LABAS, G. HARICHAUX, C.G. GRUPEN and S. P. DE GRAAF (2013): Proteomic characterization and cross species comparison of mammalian seminal plasma. J. Proteomics 91, 13-22.

14. ERIKSSON, B., H. PETERSSON and H. RODRIGUEZ-MARTINEZ (2002): Field fertility with exported boar semen frozen in the new flatpack container. Theriogenology 58, 1065-1079.

15. FERNANDEZ-GAGO, R., J. C. DOMINGUEZ and F. MARTINEZ-PASTOR (2013): Seminal plasma applied post-thawing affects boar sperm physiology: A flow cytometry study. Theriogenology 80, 400-410.

16. FRASER, L., P. BRYM, C. S. PAREEK, M. MOGIELNICKA-BRZOZOWSKA, L. PAUKSZTO, J. P. JASTRZEBSKI, K. WASILEWSKASAKOWSKA, A. MANKOWSKA, P. SOBIECH and K. ZUKOWSKI (2020): Transcriptome analysis of boar spermatozoa with different freezability using RNA-Seq. Theriogenology 142, 400-413.

17. GARNER, D. L., C. A. THOMAS, H. W. JOERG, J. M. DEJARNETTE and C. E. MARSHALL (1997): Fluorometric assessments of mitochondrial function and viability in cryopreserved bovine spermatozoa. Biol. Reprod. 57, 1401-1406.

18. GONZALEZ-CADAVID, V., J. A. MARTINS, F. B. MORENO, T. S. ANDRADE, A. C. SANTOS, A. C. MONTEIRO-MOREIRA, R. A. MOREIRA and A. A. MOURA (2014): Seminal plasma proteins of adult boars and correlations with sperm parameters. Theriogenology 82, 697-707.

19. JOHNSON, L. A., D. RATH, J. M. VAZQUEZ, W. M. C. MAXWELL and J. D. DOBRINSKY (2005):
Preselection of sex of offspring in swine for production: Current status of the process and its application. Theriogenology 63, 615-624.

20. JOVIČIĆ, M., E. CHMELÍKOVÁ and M. SEDMÍKOVÁ (2020): Cryopreservation of boar semen. Czech J. Anim. Sci. 65, 115-123.

21. KAEOKET, K., P. CHANAPIWAT, P. TUMMARUK, M. TECHAKUMPHU and A. KUNAVONGKRIT (2011): A preliminary study on using autologous and heterologous boar sperm supernatant from freezing processes as post-thawing solution: Its effect on sperm motility. Trop. Anim. Health Prod. 43, 1049-1055.

22. KNOX, R.V. (2016): Artificial insemination in pigs today. Theriogenology 85, 83-93.

23. KWON, W.-S., M.S. RAHMAN, J.-S. LEE, S.-J. YOON, Y.-J. PARK and M.-G. PANG (2015): Discovery of predictive biomarkers for litter size in boar spermatozoa. Mol. Cell Proteomics 14, 1230-1240.

24. LLAVANERA, M., A. DELGADO-BERMUDEZ, B. FERNANDEZ-FUERTERS, S. RECUERO, Y. MATEO, S. BONET, I. BARRANCO and M. YESTE (2019): GSTM3, but not IZUMO1, is a cryotolerance marker of boar sperm. J. Anim. Sci. Biotech. 10, 61.

25. MARTINEZ-LEON, E., C. OSYCKA-SALUT, J. SIGNORELLI, P. POZO, B. PEREZ, M. KONG, P. MORALES, S. PEREZ-MARTINEZ and E. S. DIAZ (2015): Fibronectin stimulates human sperm capacitation through the cyclic AMP/protein kinase A pathway. Human Reprod. 30, 2138-2151.

26. MIRANDA, P. V. and J. G. TEZON (1992): Characterization of fibronectin as a marker for human epididymal sperm maturation. Mol. Reprod. Dev. 33, 443-450.

27. NOBLANC, A., A. KOCER, E. CHABORY, P. VERNET, F. SAEZ, R. CADET, M. CONRAD and J. R. DREVET (2011): Glutathione peroxidases at work on epididymal spermatozoa: An example of the dual effect of reactive oxygen species on mammalian male fertilizing ability. J. Androl. 32, 641-650.

28. NOVAK, S., RUIZ-SÁNCHEZ, A., DIXON, W. T., FOXCROFT, G. R. and M. K. DYCK (2010): Seminal plasma proteins as potential markers of relative fertility in boars. J. Androl. 31, 188-200.

29. PEARODWONG, P., J. SUWIMONTEERABUTR, J. RUNGRUANGSAK and P. TUMMARUK (2019): Comparison of egg yolk-based and soybean lecithin-based extenders for cryopreservation of boar semen. Vet. stn. 50, 531-540.

30. PETIT, F. M., C. SERRES, F. BOURGEON, C. PINEAU and J. AUER (2013): Identification of sperm head proteins involved in zona pellucida binding. Human Reprod. 28, 852-865.

31. RODRIGUEZ-MARTINEZ, H. (2019): Semen evaluation: can we forecast fertility? Vet. stn. 50, 293-305.

32. RUNGRUANGSAK, J., J. SUWIMONTEERABUTR, K. BURANAAMNUAY, A. CHANKRACHANG and P. TUMMARUK (2021): A comparative study of two different methods to determine acrosome integrity of frozen-thawed boar sperm: FITC-PNA/ 
EthD-1 versus Coomassie blue staining. Vet. stn. 52, doi.org/10.46419/vs.52.6.4.

33. SAMARDŽIJA, M., T. DOBRANIĆ, S. KRUŠLIN, M. CERGOLJ, M. KARADJOLE, N. PRVANOVIĆ and J. GRIZELJ (2008): The use of the hypoosmotic swelling test and supravital staining in evaluation of sperm quality in boars. Vet. arhiv 78, 279-287.

34. STRZEZEK, J. (2002): Secretory activity of boar seminal vesicle glands. Reprod. Biol. 2, 243-266.

35. SUWIMONTEERABUTR, J., M. NUNTAPAITOON and P. TUMMARUK (2021): Determination of the optimal concentration of Minitube Equex paste for boar semen cryopreservation based on sperm motility characteristics. Vet stn. 52, 285-295.

36. TARDIF, S., M. D. WILSON, R. WAGNER, P. HUNT, M. GERTSENSTEIN, A. NAGY, C. LOBE, B. F. KOOP and D. M. HARDY (2010): Zonadhesin is essential for species specificity of sperm adhesion to the egg zona pellucida. J. Biol. Chem. 285, 24863-24870.

37. THURSTON, L. M., K. SIGGINS, A. J. MILEHAM, P. F. WATSON and W. V. HOLT (2002): Identification of amplified restriction fragment length polymorphism markers linked to genes controlling boar sperm viability following cryopreservation. Biol. Reprod. 66, 545-554.

38. VALENCIA, J., M. YESTE, A. QUINTEROMORENO, C. D. P. NINO-CARDENAS and F. J. HENAO (2020): Relative content of Niemann-Pick C2 protein (NPC2) in seminal plasma, but not that of spermadhesin AQN-1, is related to boar sperm cryotolerance. Theriogenology 145, 181-189.

39. VILAGRAN, I, J. CASTILLO, S. BONET, S. SANCHO, M. YESTE, J. M. ESTANYOL and R. OLIVA (2013): Acrosin-binding protein (ACRBP) and triosephosphate isomerase (TPI) are good markers to predict boar sperm freezing capacity. Theriogenology 80, 443-450.

40. VILAGRAN, I., M. CASTILLO-MARTIN, N. PRIETO-MARTINEZ, S. BONET and M. YESTE
(2016): Triosephosphate isomerase (TPI) and epididymal secretory glutathione peroxidase (GPX5) are markers for boar sperm quality. Anim. Reprod. Sci. 165, 22-30.

41. VILAGRAN, I., M. YESTE, S. SANCHO, J. CASTILLO, R. OLIVA and S. BONET (2015): Comparative analysis of boar seminal plasma proteome from different freezability ejaculates and identification of Fibronectin 1 as sperm freezability marker. Andrology 3, 345-356.

42. WABERSKI, D., A. RIESENBECK, M. SCHULZE and K. F. WEITZE (2019): Application of preserved boar semen for artificial insemination: Past, present and future challenges. Theriogenology 137, 2-7.

43. WYSOCKI, P., A. ORZOŁEK, J. STRZEŻEK, M. KOZIOROWSKA-GILUN, Ł. ZASIADCZYK and W. KORDAN (2015): The activity of N-acetyl$\beta$-hexosaminidase in boar seminal plasma is linked with semen quality and its suitability for cryopreservation. Theriogenology 83, 1194-1202.

44. YESTE, M. (2015): Recent advances in boar sperm cryopreservation: State of the art and current perspectives. Reprod. Dom. Anim. 50 (Suppl 2), 71-79.

45. YESTE, M. (2016): Sperm cryopreservation update: Cryodamage, markers, and factors affecting the sperm freezability in pigs. Theriogenology 85, 47-64.

46. YESTE, M., E. ESTRADA, I. CASAS, S. BONET and J. E. RODRIGUEZ-GIL (2013): Good and bad freezability boar ejaculates differ in the integrity of nucleoprotein structure after freeze-thawing but not in ROS levels. Theriogenology 79, 929-939.

47. ŽURA ŽAJA, I., M. SAMARDŽIJA, S. VINCE, I. MAJIĆ-BALIĆ, M. VILIĆ, D. ĐURIČIĆ, S. MILINKOVIĆ-TUR (2016): Influence of boar breeds or hybrid genetic composition on semen quality and seminal plasma biochemical variables. Anim. Reprod. Sci. 170, 75-82. 


\section{Razlika između proteina sjemene plazme i proteina sperme za dobru i lošu sposobnost smrzavanja ejakulata nerasta}

Janyaporn RUNGRUANGSAK, Semen Quality Control and Research Section, Bureau of Biotechnology in Livestock Production, Department of Livestock Development, Muang, Pathum Thani, 12000 Thailand; Junpen SUWIMONTEERABUTR, Swine Reproduction Research Unit, Department of Obstetrics, Gynaecology and Reproduction, Faculty of Veterinary Science, Chulalongkorn University, Bangkok 10330, Thailand; Kakanang BURANAAMNUAY, Institute of Molecular Biosciences, Mahidol University 25/25 Phuttamonthon 4 Rd., Salaya, Nakhon Pathom 73170, Thailand; Sariya ASAWAKARN, Biochemistry Unit, Department of Physiology, Faculty of Veterinary Science, Chulalongkorn University, Bangkok, 10330, Thailand; Naphat CHANTAVISOOTE, Trairak PISITKUN, Chulalongkorn University Systems Biology, Faculty of Medicine, Chulalongkorn University, Bangkok, 10330, Thailand; Kamon CHAWEEWAN, Swine Research and Development Centre, Department of Livestock Development, Nakhon Ratchasima, Thailand; Padet TUMMARUK, DVM, MSc, PhD, Swine Reproduction Research Unit, Department of Obstetrics, Gynaecology and Reproduction, Faculty of Veterinary Science, Chulalongkorn University, Bangkok 10330, Thailand

Ova studija provedena je u svrhu usporedbe ekspresije proteina sperme, tj. trioza-fosfat izomeraze (TPI) i akrozinvezujućeg proteina (ACRBP) te proteina sjemene plazme, tj. glutation peroksidaze 5 (GPX5) i fibronektina 1 (FN1), u sjemenu nerasta s dobrom, umjerenom i lošom sposobnošću smrzavanja. Studija je provedena ustvrđivanjem sadržaja proteina u 32 uzorka sperme i 38 uzoraka sjemene plazme sjemena. Ejakulirano sjeme podijeljeno je u dva dijela: prvi dio je centrifugiran za odvajanje taloga sperme od sjemene plazme, a drugi je dio je krioprezerviran. Nakon odmrzavanja u skladu s pokretljivošću spermija nakon odmrzavanja ejakulati su klasificirani u tri skupine: dobra $(60,2 \pm 1,7 \%)$, umjerena $(29,3 \pm 2,0 \%)$ i loša $(16,6 \pm 2,2 \%)$ sposobnost smrzavanja. Ekspresije GPX5 i FN1 u sjemenoj plazmi te TPI i ACRBP u spermi ustvrđene su „Western blot" analizom. Za proteine sperme je otkriveno da je razina TPI nakon odmrzavanja negativno povezana s ukupnom pokretljivošću sperme $(\mathrm{r}=-0,38, P=0,029)$. $\mathrm{Za}$ proteine sjemene plazme, razina FN1 u sjemenoj plazmi nakon odmrzavanja pozitivno je povezana s ukupnom pokretljivošću sperme nakon odmrzavanja $(\mathrm{r}=0,37, P=0,021)$ i progresivnom pokretljivošću $(r=0,39, P=$ 0,016). Ekspresija GPX5 nije povezana ni sa kakvim kvalitetama smrznute pa odmrznute sperme $(P>0,05)$. Zaključno, sjeme nerasta koje sadrži visoku razinu FN1 u sjemenoj plazmi ima bolju sposobnost smrzavanja. Pokretljivost sperme koja je smrznuta pa odmrznuta pozitivno je povezana s razinom FN1 u sjemenoj plazmi nerasta, a negativno s razinom TPI u spermijima nerasta.

Ključne riječi: nerast, krioprezervacija, sposobnost smrzavanja, protein, sperma 